\title{
Revisiting Missions: Decolonizing Public Memories in California
}

\author{
Brenda Helmbrecht
}

\begin{abstract}
Living in California seems to require interaction with the state's twenty-one historic Spanish missions, either by visiting them as a tourist, driving by a mission in one's neighborhood, or learning about them as a schoolchild. While the missions ostensibly celebrate California's history, many promote an anachronistic and dishonest re-telling of history that elides the devastating impact of the missions on Native communities (both historically and today). The missions operate as largely uncontested tourist attractions that promote self-serving collective memories about California's founding narrative. Rhetorical analysis, I argue, can lead to a more honest engagement with the "hard truths" of their pasts, thus enabling a decolonizing paradigm (Lonetree). Toward this end, this essay focuses on the missions' role in shaping public memory in California by comparing the rhetorical choices made at two locations: Mission San Luis Obispo de Tolosa and La Purisima Mission State Park.
\end{abstract}

Keywords: California Indigenous people, California missions, decolonizing museums, memory, spatial rhetorics

Places are leaky containers. They always refer beyond themselves. ... What we call places are stable locations with unstable converging forces that cannot be delineated either by fences on the ground or by borders in the imagination.

-Rebecca Solnit, Infinite City: A San Francisco Atlas, vii

Solnit's depiction of places intertwines with recent debates regarding the purpose and meanings attached to Confederate monuments. Statues, plaques, and even the names of buildings and public spaces have been slowly leaking their histories and becoming newly visible. For instance, as more communities recognize the "Lost Cause" ideologies many Confederate monuments embody, these markers no longer hide in plain view as passive purveyors of historical accounts. In his speech addressing the removal of Confederate statues in New Orleans, Mayor Mitch Landrieu questioned how these monuments affect citizens: "While some have driven by these monuments every day and either revered their beauty or failed to

Brenda Helmbrecht is Professor of English, California Polytechnic State University, San Luis Obispo, Department of English, 47-32 1 Grande Ave., San Luis Obispo, CA 93407, USA. E-mail: bhelmbre@calpoly.edu 
see them at all, many of our neighbors and fellow Americans see them very clearly" (qtd. in Cosson par. 47). Memorial objects, like the New Orleans statue commemorating Confederate General Robert E. Lee, shape how citizens privately and collectively remember their city's past and, in turn, affect how they understand the present. Recontextualizing and sometimes removing these objects shows that historical events can be remembered without antagonizing and threatening people's safety and welfare today.

By removing Confederate statues, New Orleans, along with other cities and even college campuses, may be coming to terms with the idea that a public space carries many meanings; as Solnit suggests above, spaces "always refer beyond themselves" by embodying competing ideologies and beliefs. As people challenge how their present surroundings represent the past, difficult dialogues about shared histories begin to flow. Mayor Landrieu argues, "To literally put the confederacy on a pedestal in our most prominent places of honor is an inaccurate recitation of our full past, it is an affront to our present, and it is a bad prescription for our future" (qtd. in Cosson par. 35). California often seems distant from the debates surrounding Confederate monuments. My students watch iconic, racist images being removed in the South and note that it's good that those states way over there are finally addressing their racism and hate. Yet they seldom note the parallel discussions happening around them as California begins addressing its own challenges with historic remembrance.

In September 2018, Stanford University removed Father Junípero Serra's name from a dormitory, a campus building, and the "Serra Mall" pedestrian walkway. Serra, a Spaniard who founded nine Catholic missions in California between 1769 and 1782, is generally regarded as the Father of the California mission system, which lasted sixty-four years. His legacy rests with the twenty-one missions spread along 700 miles of the California coast, each standing as a reminder of the clash between Indigenous and Spanish cultures in the seventeenth and eighteenth centuries. Serra's name has been attached to California's roads, parks, schools, and libraries. In short, Serra and his influence loom large throughout the state.

However, Serra and the other missionaries who colonized Alta California for Spain are increasingly regarded as colonial oppressors who committed genocide against Indigenous people. In covering Stanford's decision, the Los Angeles Times reported, "Native American students and staff and tribal leaders in Northern California" told Stanford's Advisory Committee on Renaming Junípero Serra Features "that the impacts of the missions were long lasting and harmful.... Those in the school community spoke 'of visceral feelings of harm, trauma, emotional damage, and damage to their mental health' from seeing Serra's name around campus" (Kohli par. 8). The missions, which have traditionally blended into California's landscapes, may now rest uneasily in their communities.

In this essay, I examine historical and present-day contexts that inform how the Spanish Catholic missions function as sites of remembrance in California. 
Most missions operate as heritage tourist sites that promote a kind of "fantasy past" where memory and history are constantly in tension. I argue that missions might ease this tension by unequivocally taking more responsibility for the trauma inflicted on Indigenous communities both historically and today. By adopting "decolonizing museum practices," as described by Amy Lonetree, missions can become sites where communities engage honestly with the state's history of genocide. To illustrate how the missions shape the relationship between memory and history, I examine two locations: Mission San Luis Obispo de Tolosa, a Catholic-run mission, and La Purisima Mission State Historic Park, one of three secular missions managed by the California Department of Parks and Recreation. Contrasting a mission with an active sacred life to a secular mission site attempting to confront its historical legacy helps me highlight the competing rhetorical choices the two locations make to convey a historical narrative about the ongoing "missionization" of California.

When I first started teaching at California Polytechnic State University fifteen years ago, I had never heard of a California mission. My interest in our local mission-and, by extension, the twenty other missions along the coast -is inspired by how communities gather around them. Many missions gloss over the political, racial, and religious conflicts inherent in the mission system: the bloody Native uprisings, crippling starvation, physical and emotional abuse, the isolation of girls and women, and the spiritual and philosophical lives of Natives before missions dominated their lives. Indeed, many historians have already explored the catastrophic impact of mission life on Indigenous cultures (see Castillo; Hackel; Jackson and Castillo; Kryder-Reid; Reyes; Sandos). These histories help me position the missions as complex rhetorical sites that reinforce the cultural and racial assumptions that motivated Spanish missionaries centuries earlier. However, academic histories often seem to exist in one realm, while the historical narratives conveyed at the missions themselves exist in another. When comparing the accounts told by some missions with the narratives that could be told, many sites seem willfully detached from the deeper, more intricate histories at which they only hint.

While visiting each of the twenty-one missions, I have come to see the mission system as essential for framing collective memories and perceptions about California's colonialist history. Mission history is built into the state's fabric. I approached my tours with the same questions: What do visitors learn about the history of the mission system by walking their grounds? What rhetorical choices do missions make to convey stories of Spanish colonization in California? And perhaps most importantly, how do missions themselves shape public memory about Indigenous history? 


\section{Constructing Public Memories}

California's missions are over two hundred years old and literally stand for the state's founding heritage. While looking to heritage studies will help ground my analysis, a theoretical turn to memory and museum studies will show how heritage sites function rhetorically. In Pluralising Pasts: Heritage, Identity and Place in Multicultural Societies, G.J. Ashworth, Brian Graham, and J.E. Tunbridge propose that contemporary needs shape the histories circulated by heritage places: "The contents, interpretations and representations of the heritage resource are selected according to the demands of the present" (4). In other words, the meanings heritage sites create may be driven less by facts and evidence than by wishful thinking, or "what might, could or should have been" (40). Indeed, touring missions often requires visitors to untangle history from myth to understand the experiences of Indigenous peoples. Bryony Onciul locates responsibility for shaping the meanings crafted by heritage places within the groups who manage and curate them. In Museums, Heritage, and Indigenous Voice: Decolonising Engagement she highlights the "power and authority" of the communities and organizations "that build and authorize" heritage locations (3). When agents like Catholic leaders and parishioners control the missions' historical narratives, they ultimately control remembrance. Onciul echoes Ashworth et al. when she suggests that communities seeking to extol their heritage can inadvertently construct simplistic, essentialist historical narratives: "by selecting aspects of their identity for museum display, [communities] demarcate the elements they view as essential and freeze them in static form in an exhibit" (165). Further, if communities privilege a dominant perspective over others-such as Native members of the community - the opportunity to grapple with historical evidence diminishes.

In building their historical narrative, the missions align with other popular heritage sites that disengage from difficult truths. For instance, Kristan Poirot and Shevaun Watson identify Charleston, South Carolina, as a destination for heritage tourism that often dodges an obligation to engage with its past. Their article, "Memories of Freedom and White Resistance: Place, Tourism, and Urban Slavery," highlights Charleston's "tourism imaginary - [or] a manufactured version of the city" (93, emphasis in the original), where gentility, architectural beauty, and tenacious survival shape the city's identity, which, in turn, engineers pleasant memories for tourists about slavery in the South. By encouraging tourists "to participate in a fantasy that propels a visitor's escape from his/her ordinary preoccupations" (98), Charleston presents itself more as a vacation spot than as a site of historic trauma. Approaching tourism with a visitor's comfort in mind results in many of the city's millions of sightseers encountering sanitized representations of slavery. Both California's missions and Charleston's slavery tourism industry could instead adopt more progressive practices to "vivify narratives in ways that contour visiting publics' material experiences of a locale and latent beliefs about our nation's past" (93). In other words, heritage tourism can either 
challenge "latent" and, in some cases, false beliefs, or it can reify those beliefs, leaving them undisputed.

In framing Charleston as a "memory landscape" (94), Poirot and Watson turn to Greg Dickinson, Carole Blair, and Brian L. Ott's Places of Public Memory: The Rhetoric of Museums and Memorials. In their introduction, the authors suggest that shared, public memories form easily if the memory is embedded within a destination or "memory place" that "typically require[s] visitors to travel to them" (26). Tourists anticipate memory places to be a "departure from the ordinary" where they "encounter rare or unique relics, learn about highly significant people or events, and/or [are] moved in particular ways by the experience of the place" (26). As they walk the very hallways and occupy the same rooms as Franciscans did centuries ago, mission tourists leave their present moment and embody the past. In this memory space, they are encouraged to identify with hardships the padres experienced: isolation, famine, a desire to fulfill a religious calling. Empathizing instead with Natives who suffered in these spaces requires a visitor to face difficult realities and may not be the "departure from the ordinary" they seek.

Dickinson, Blair, and Ott's depiction of the relationship between memory and location is complicated further if we regard memory sites as mediaries between a person and a remembered past. In Prosthetic Memory: The Transformation of American Remembrance in the Age of Mass Culture, Alison Landsberg coins the phrase "prosthetic memory" to describe a way of remembering that "emerges at the interface between a person and a historical narrative" (2). In response to experiencing a historical site, a visitor "sutures himself or herself into a larger history ... and takes on a deeply felt memory of a past event through which he or she did not live" (2). I suggest the actual mission sites serve as the interface Landsberg describes. While many missions seem committed to forgetting the Natives' experiences, visitors want to remember their own experiences. So they take photos, buy postcards and magnets, or attend church services, and, in turn, form positive, prosthetic memories to help them remember the missions. In other words, these mediated memories enable people "to feel a connection to the past" so they can actually "remember their position in a contemporary moment" (9). By not questioning the church's version of its history, visitors unwittingly find themselves more empowered to forget than remember.

Indeed, heritage sites and their museums are uniquely vested with "the power to both remember and forget" (Onciul 3). While museums are only one element found in most missions, the responsibility for portraying mission history usually falls to them. In a review of scholarship focusing on the rhetoric of museum practices, Susan Mancino concludes, "museum rhetoric remains a powerful source in shaping public memory, constructing cultural authority, and enabling public forgetting" (266). Mission museums often trust that displaying familiar Native artifacts-arrowheads, woven baskets, beads-will present a cohesive historical 
narrative. Yet these artifacts do not necessarily teach anything specific about life at the mission. Instead, they promote a stereotypical and homogeneous understanding of "Indians," thereby encouraging an easy recognition of mission life. In the introduction to Mediating Memory in the Museum, Silke Arnold-de Simine posits that a focus on familiarity is perhaps more commonplace in privately owned museum spaces: "Museums-especially but not exclusively those that are privately funded-need their customers to approve of the exhibition rather than feel challenged beyond their comfort zone" (2). While some museums-such as Washington, DC's Holocaust Memorial Museum or the National Museum of African American History and Culture-challenge visitors' historical memories, other museums, like many at the missions, wallow in nostalgia for a time that never existed. As inherently rhetorical spaces, museums curate both historical remembering and forgetting.

The impulse to understand the past through emotional, experiential, or political needs of the present points to an exigence: heritage sites may need to be understood through a different lens. Rather than turning to the comfort of nostalgia, we can, instead, decolonize heritage spaces and the memories we have constructed about them. In Decolonizing Museums: Representing Native America in National and Tribal Museums, Lonetree argues that by "working from a decolonizing paradigm," museums that represent Native experiences can "assist communities in their efforts to address the legacies of historical unresolved grief by speaking the hard truths of colonialism and thereby creating spaces for healing and understanding" (7, 5). By contending with "hard truths" (a phrase Lonetree uses throughout her book), the organizations and individuals managing the missions might make different choices about which artifacts to display and the language used to describe them. The missions could then ask visitors to join them in confronting their pasts.

Yet meaning is not just created by the missions, for as tourists move through spaces, they contribute to the space's meanings too. In Geographies of Writing: Inhabiting Spaces and Encountering Difference, Nedra Reynolds explores how bodies and spaces create meaning together: "a body becomes marked with the residue of a place, but places are also changed by the presence of bodies" (143). If more bodies question arguments made by heritage sites rather than reflexively observing artifacts and ambling through structures, the spaces may begin to decolonize as representations of history change. I am hinting at a process here: if missions shape their founding narratives to hew more closely to the historical record, they could begin to decolonize, and public memories of Native history could begin to decolonize in response.

How can tourists grapple with the meanings created by colonized spaces when they inhabit and dwell in them? As Reynolds shows, dwelling and memory are deeply intertwined: "Our spatial practices of the everyday or our way of being in the world are formed through the memories that make [spaces] at first familiar, 
perhaps comforting, and then habitual" (156). The sensation of comfort and familiarity one feels when walking in a mission needs to be disrupted. If dwelling in missions includes contemplating difficult truths and linking history to modernday racism and oppression, dwelling can become a decolonizing practice that challenges how these spaces function rhetorically. Perhaps dwelling can also create a discomfort that leads to more nuanced understandings of historical agency. By "naming colonialism and its ongoing effects" (Lonetree 7), missions can commit to adopting a decolonizing paradigm and encourage a kind of dwelling that inspires critical interrogation of historical memory.

\section{The Enduring Histories and Memories of the Missions}

Adopting a decolonizing paradigm first requires engagement with historical evidence. The first mission was established in San Diego in 1769 by Serra; the last was founded in what is now Sonoma in 1823. While Spain sent Serra to claim land in Alta California before Russia, Serra was motivated by a deeper calling to save souls. When Serra arrived in a new territory, he and his fellow missionaries claimed it for Spain and began making contact with local Natives. Many neighboring tribes first looked at the colonizers with curiosity: the Spanish Franciscans and soldiers had guns and food and were unlike anyone else they had encountered. Serra reluctantly understood that without the expertise of the local Natives, his aspiration to baptize them would not be fulfilled.

In Converting California: Indians and Franciscans in the Missions, James Sandos explains that as soon as an Indigenous person was baptized, the Franciscans took on the role of guardian or parent of the Native "neophytes" and were legally responsible for their "management, control, punishment, and education" (53). Once baptized, the Natives became property of the mission and were forbidden from returning to their tribes and families without permission. They became a mission's workforce: they built the missions, and became blacksmiths, farmers, cooks, and seamstresses. They raised livestock, made wine, tended gardens, and developed aqueducts. Long days and punishing work prevailed.

Spanish soldiers stationed at the missions and nearby presidios hunted down runaway Natives, who were often punished with lashes and imprisonment on their return. In A Cross of Thorns: The Enslavement of California's Indians by the Spanish Missions, Elias Castillo concludes, 'Underlying the Franciscan friars' disdain of the Indians was the fact that they valued the souls of their captives far more than their material existence on earth" (2). To support Castillo's assertion, we need only to look to the Franciscans' own meticulous records: just as they noted yearly crop yields and livestock populations, they recorded each "neophyte" baptism. These records were sent back to Spain as proof of the missions' success.

But as stories of European contact always seem to go, Native populations soon saw their lands and resources stolen while their family members died from illnesses and starvation. Even Father Lasuén, who oversaw the mission system 
after Serra died in 1784, observed in a letter to a superior in Spain, "the majority of neophytes have not acquired much love for our way of life; and they see and meet their pagan relatives in the forest, fat and robust and enjoying complete liberty" (qtd. in Sandos 93). Additional first-person European accounts discuss the demeanor and mood of mission captives. For instance, French explorer Jean François de La Pérouse led a 1785 expedition around the world at the behest of Louis XVI. He arrived at the mission in Monterey Bay in 1786.

In his introduction to La Pérouse's journal entries, Malcolm Margolin explains that the Franciscans and Natives at Mission San Carlos Borromeo de Carmelo lived in squalor: "The sixteen years since [the mission's] founding had been exceptionally harsh. Crops failed repeatedly, supply ships from San Blas failed to come when needed, and the Indians proved deeply resistant to European ways" (14). The missions were isolating and the task for "two monks and a handful of soldiers" to re-create "European civilization with the Indians of California as its citizenry" proved impossible and demoralizing (15). Franciscans seldom entertained European visitors, so La Pérouse's arrival would have been celebrated. The padres and neophytes would have worn their best garments, cooked the best possible food, and been on their best behavior.

Despite the padres' attempts to be amiable hosts, La Pérouse observes that the mission Natives-in appearance, temperament, and treatment-"scarcely differ from that of the Negro inhabitants of [France's] colonies" (70). He also describes the atmosphere of the mission, noting that he saw "men and women in irons, others in stocks. Lastly, the noise of the whip might have struck our ears. ... [M]any sins, which in Europe are left to Divine justice, are here punished" $(81,82) .{ }^{1} \mathrm{La}$ Pérouse's journal is remarkable not only for the thorough description of mission life but also for the ways he gently criticizes the padres' lack of humanity and empathy. He laments, "I could wish that the minds of the austere, charitable, and religious individuals I have met within these missions were a little more tinctured with the spirit of philosophy" (71). While modern-day mission advocates urge critics not to apply twenty-first-century sensibilities to eighteenth-century events, contemporary reports-which are seldom discussed in today's missions-also questioned the Franciscans' treatment of Natives.

Before contact with Spanish colonists around 1769, roughly 65,000 Indigenous people resided in Alta California. After winning its independence from Spain, Mexico secularized the missions in 1833 , at which point the Native population numbered 17,000 (Sandos 1). While the padres had always promised to return the land to their neophytes, Mexico redistributed the missions' lands to Mexican rancheros and soldiers. Many Natives had nowhere to go after secularization; they had been born at the mission and knew no other life.

\footnotetext{
${ }^{1}$ Castillo describes similar punishments witnessed by fur trappers, traders, and even military prisoners.
} 
While I have offered only a glimpse into mission history, I believe I have offered more historical details than many visitors will encounter when visiting most missions today. While touring the missions, I studied how these sites "talk" about their own history through museum displays, signage, tours, and in-house texts like websites and pamphlets-the "rhetorical resources" that help to construct public memory (Blair et al. 13). After encountering a church, museum, gift shop, burial site, and garden, mission visitors are left to piece together these resources and form a clear understanding of the historical and current relationships between the Catholic Church and Native tribes. Such synthesis can be hard to do, especially in a space that discourages such rhetorical and interpretive work. The mission history presented in state-run and religious locations relies on linear narratives, or on a series of dates and events. The inner lives of Natives who lived and even died at the missions are often left out of the story of the missions' founding, closing, and eventual restoration.

Missions make arguments about the limited importance of Indigenous lives by continuing to leave them out of the narrative or by misrepresenting their experiences. If visitors leave the missions with the same mis-remembrance, the shared public memory moves further and further away from historical evidence and hard truths. In other words, the missions advance a specific fantastical remembrance, one that serves the interests, needs, and desires of the present. As tourists, our impulse is to trust what we are told; we imbue heritage sites with authority. At the missions, critical questions are easily subdued by picturesque architecture and scenery and by the quiet reverence that sites of worship tend to invoke. Touring with an air of respect and faith seems appropriate in an explicitly religious site. However, when that history is, at best, skewed, and at worst, dishonest, false memories of events are created and become difficult to dismantle.

\section{Competing Sites of History}

Why do we seek out historic sites? Perhaps we want to feel part of and contribute to a historical moment; we want to remember and dwell in a space's human stories. However, the relationship between memory and history becomes messy if the individual or group conveying the historical narrative offers perspectives that can make visitors uncomfortable, or, in the case of the missions, compels them to criticize the church. California's missions still reside in their original contexts. They intertwine the actual historical record (informed by evidentiary documents) with their own curated histories (informed by past and present religious doctrine), to create a confused jumble of commercialism, history, and memory. Missions encourage visitors to encounter the past, and, if an honest history is told, this knowledge could enable people to "rethink and reshape" their present-day selves (Landsberg 9). Unfortunately, I doubt such a transformation happens for most visitors. 
Although missions throughout California have similar histories, the historical narratives conveyed in religious locations and state parks differ greatly. By focusing on two missions in particular-a kind of spatial case study-I hope to extend my analysis to show how missions throughout California could communicate more accurate histories to visitors. Mission San Luis Obispo de Tolosa remains an active Catholic parish; sixty miles south, the secular La Purisima Mission State Park is operated by the state of California. Their proximity to one another ensures that, geographically and culturally speaking, the Franciscans met some of the same challenges when founding the missions. Moreover, generations of Chumash Natives settled the land surrounding both locations and were compelled to build and live at them. Although one site is secular and the other religious, they maintain the same features: a church, museum, gift shop, and gardens. ${ }^{2}$ But Missions San Luis Obispo and La Purisima rely on different rhetorical tools to help visitors remember their colonialist histories. I suggest that La Purisima is actively working from a decolonizing paradigm to help visitors engage with difficult elements of state history. In many ways, history leaks out of La Purisima in a richer, more objective way than at San Luis Obispo.

\section{Mission San Luis Obispo de Tolosa, Founded by Father Junípero Serra in 1772}

The plaza in front of Mission San Luis Obispo (SLO) is a gathering spot where community members, tourists, and college students attend free summer concerts, occasional protests, and "Pride in the Plaza," the annual LGBTQ [lesbian, gay, bisexual, transgender, and queer/questioning] Festival. Perhaps with an ice cream cone or a cup of coffee, people stroll along the creek that runs in front of the mission and winds through downtown. Lush gardens surround the mission; visitors can sit on benches surrounded by grape vines and blooming flowers all year round. Because the mission is situated downtown, the adjacent streets and sidewalks are quite busy and noisy. ${ }^{3}$

The Catholic Church owns and maintains Mission SLO (Figure 1). The mission's website presents it as a religious place. For instance, the "Pastor's Message" video describes the mission as the "heart of a living community of faith ... serving the spiritual life of the Central California coast for generations." The website also touches on the mission's history: "For more than two centuries, Mission San Luis Obispo has greeted travelers, pilgrims, and guests with open doors and a place to rest." Parishioners attend religious services, baptisms, and weddings in the chapel, the walls of which feature hand-painted flowers, shells, birds, and plants. The

\footnotetext{
${ }^{2}$ One significant difference is the presence of graveyards. Like many missions, La Purisima acknowledges the Natives and religious leaders buried at the location in what are essentially mass graves. San Luis Obispo moved its graveyard in the 1990s to another location to make room for a new wing on the church.

${ }^{3}$ Unless otherwise indicated, the photos throughout this article were taken by the author.
} 


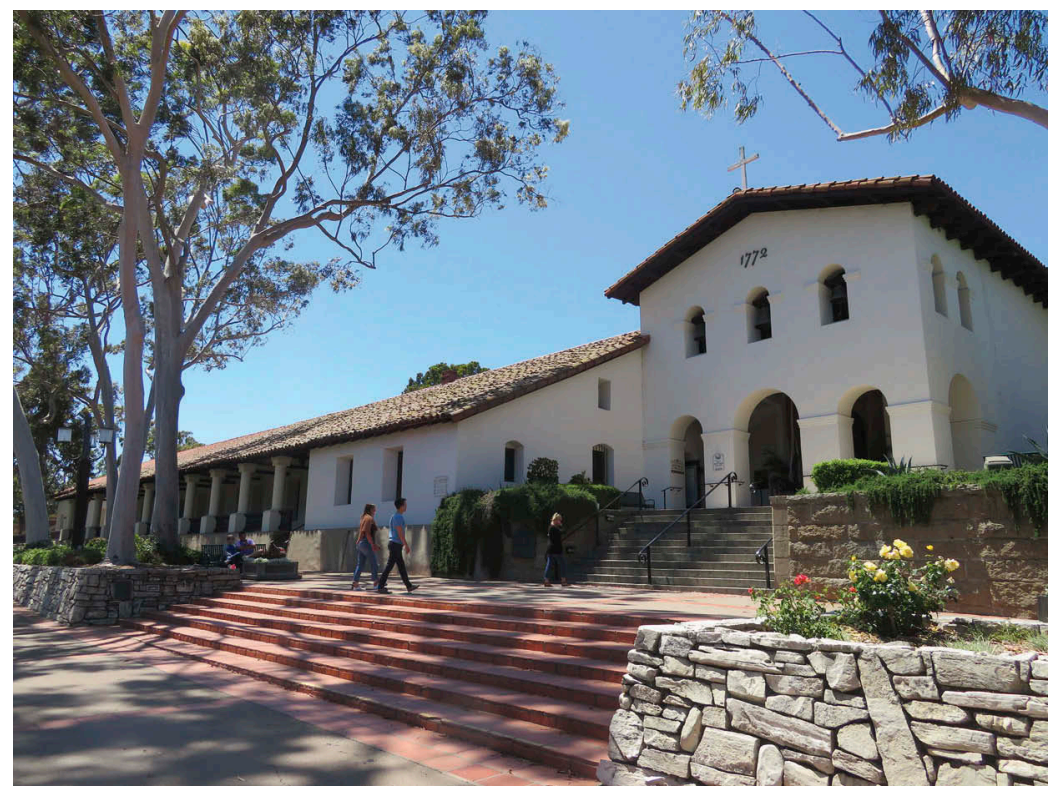

Figure 1 Mission SLO and its front plaza.

ceiling is painted with stars. The naturalistic imagery was completed by an artist in 2001, who, according to a local news report, wanted to "incorporate some of the 'missing influence' of the American Indians who built the Mission and also enhance the influence of Spanish, Mexican and Moorish concepts of those who directed them" (Roberts A11). Perhaps bringing nature into the church makes some space for a Chumash perspective, but this visual connection is not made explicit. Indeed, many visitors assume the artwork is original to the eighteenth century. The church does not mention the Chumash who built and died in the mission.

Sitting adjacent to the church, a gift shop spans three rooms inside what used to be the padres' living quarters. The shop sells stereotypical "Native American" tchotchkes, like dreamcatchers and pan flutes-items that really have nothing to do with the area's tribes but that commodify and represent "Native" culture nevertheless. This Native pastiche sits alongside religious emblems like crucifixes and bottles of holy water. Mission memorabilia, including magnets, models, and postcards, are also available for purchase. The mission's only visible employee sits behind the cash register, which seems common for most religious sites, where there are few, if any, full-time docents or volunteers to answer questions. The museum's free brochure and signage are the only sources for information about the exhibits.

The layout of the museum signifies a commitment to chronology. The museum presents the transition from mission life to secularization to the development of 
rancheros as seamless and painless, except, perhaps, for the padres who lost their churches and returned to Spain. To present this chronology, the museum focuses not on concepts or ideas (such as Native sovereignty or secularization and its effects) but on objects (Lonetree 46-48). I liken the museum to a depository organized around cabinets of curiosities, as opposed to an instrument devoted to educating a public about its cultural heritage. The museum's first two rooms feature glass cases filled with mostly unlabeled artifacts such as pottery, baskets, and stone grinding tools like metates (Figure 2). The museum does not indicate which tribes made or used the items, or even if these artifacts are directly connected to the mission's history. The arrows and baskets seemingly stand in for actual Chumash voices and perspectives, otherwise absent from the space.

Native lives and voices emerge sporadically throughout the rest of the museum, but they are quickly subsumed by a focus on local history, as well as by the padres' piety, achievements, and suffering. Dozens of meticulously labeled photographs of SLO's founding residents cover the walls, while the glass cases under them display early twentieth-century clothing and children's toys. Rooms exhibiting housewares, furniture, and agricultural tools ask visitors to imagine the lives of settlers in SLO. One room is set up to look like a 1920s rectory dining room; others present religious vestments, song books, and paintings. A spartan bed and drab wool robe show how the padres slept and dressed.

An article published in the San Luis Obispo County Telegram-Tribune in 1978 profiles Sandra Buchman, "an earnest young woman" who tried to re-organize the museum (Cook A4). The handful of familiar images included in the article

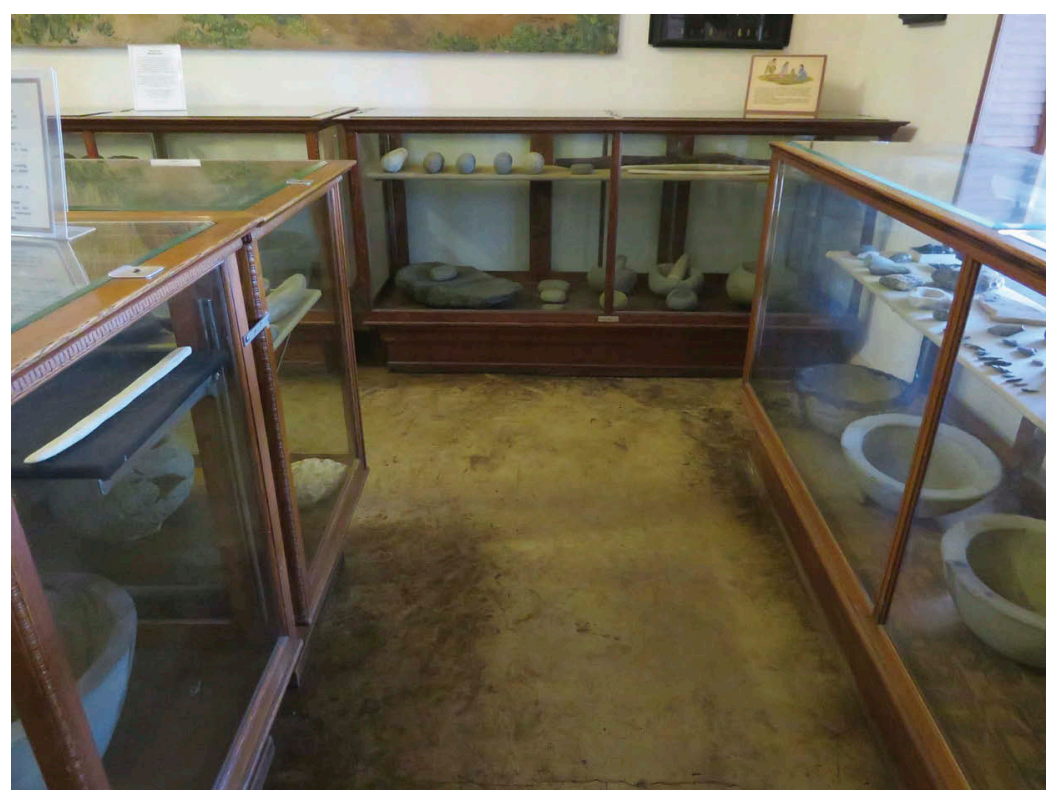

Figure 2 Display cases in the Mission SLO museum. 
present elements of the museum as they still appear today. I suspect little has changed since Buchman's efforts, and I find further evidence for this suspicion when I pair the news article with a placard in the museum. Buchman guesses that a hole in a mission door was used by "the two cats assigned to each mission to keep mice down" (qtd. in Cook A4). A museum sign claims that an original mission door on display contains a "cat door" for the two cats each mission received "to control mice." Buchman is not cited as the source of this theory, but it stands to reason that the interpretation is hers. In other words, the museum has not updated many of its exhibits in decades.

This same sign also hints at a significant reality of mission life: the metal bars on the door's window could signify the confinement of Native women and girls. The padres held women to Christian standards of chastity, a practice which, Bárbara O. Reyes suggests, disrupted normal social interactions (124). In Private Women, Public Lives: Gender and the Missions of California, Reyes describes the monjerios, or nunneries, where unmarried girls and women were locked at night, segregated from men (including young girls' fathers). The padres effectively controlled women's sexual and reproductive lives and successfully "sever[ed] the processes whereby [children] would learn their traditional beliefs and way of life" (53). In fact, those simple bars could actually represent an opportunity to tell the truth about mission life for Native women.

The many handwritten and laminated signs placed haphazardly throughout the museum seem to be from a different era (Figure 3). Their "arts and crafts" aesthetic feels out of synch with the weight of the information they report.

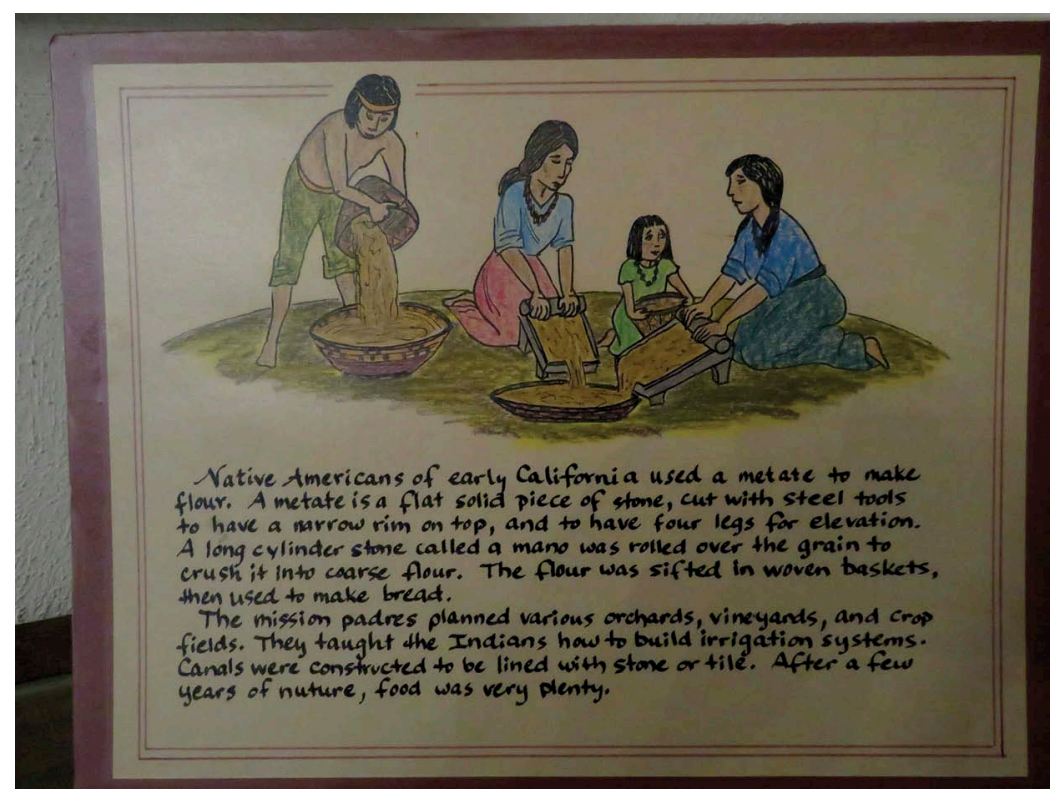

Figure 3 Sign above a display case filled with stone grinding tools. This sign can also be seen sitting on a display case in Figure 2. 
Some depict the Chumash using cartoonish drawings, which has a kind of dehumanizing, detached effect, as though the Chumash are playing a role in a children's storybook. The handwritten script adds to this impression.

Another, more formal, printed sign explains, "For thousands of years, California had remained unchanged. Even the entry of the missions did little to alter the character of the land." Real change, the mission explains, came with the Gold Rush. While the construction of missions absolutely changed the state's landscape, missions are presented as a benign presence. A sign near the garden entrance tries to offer a quick history of the mission system. While the information mostly aligns with the historical record, the language still favors a colonizer's vantage point. Here, the mission highlights the blending of "religious desires and political aims," yet these aims belong to the Franciscans and Spain; the aims of the Natives are elided. The "Indians" are described as "peaceful," which could indicate that they did not revolt against their oppressors (they did). Finally, the sign explains that Friars were more interested in conversion than building empire, when of course empires are built through forced conversion and assimilation. The two cannot be separated.

A tour of Mission SLO led by a volunteer did not take our group to the museum as I had expected. Rather, we explored the church for an hour as she focused on the lives and work of the padres. The guide used the same passive voice construction as the mission; that is, "the mission was built in 1772" (tour); "Indians had been decimated by disease" (mission pamphlet; "Welcome"); building the mission "was accomplished with the aid of the local Chumash Natives" (mission website). In "California's Sites of Conscience: An Analysis of the State's Historic Mission Museums," anthropologist and art curator Deana Dartt-Newton notes the "use of passive voice in the museum ... to avoid identifying injustice or laying blame" (101). As a rhetorical choice, passive voice masks those who are doing the acting, the laboring, and the suffering.

The mission privileges a romantic narrative wherein two cultures harmoniously merge. Behind a case of mortar and pestles, a large painting titled "Sunset at Shelter Cove" features Chumash families working peacefully in the yellow-orange glow of the sun setting over the ocean. Far on the horizon, a tiny ship floats on the tranquil water. The painting radiates feelings of hope and prosperity. The sign next to the painting explains:

This historical mural depicts a family of Chumash Indians at eventide in the autumn of 1542, [sic] In the distance the San Salvador, under the command of Juan Rodrigues Cabrillo, rides at anchor. This epoch [sic] voyage marked the first exploration of these Pacific coastal waters. Nationally renowned artist Shirley Lennox, has beautifully, realistically, and accurately pictured, through extensive research, what might have been witnessed at that moment in time. (emphasis added)

The terms "realistically" and "accurately" ask visitors to regard this painting as offering a factual depiction of first contact between Europeans and Natives, although we do not know what Natives witnessed when they saw boats on the horizon. Lennox is identified 
as a "nationally renowned artist," yet I found very little information about her. In 1986, the Los Angeles Times referenced her in its "Gold Coast Calendar of Events": "A series of acrylic paintings by Santa Maria artist Shirley Lennox, will be on display. ... The paintings were inspired by Lennox's mural for a scene from Chumash Life ('Sunset at Shelter Cove') in the lobby of Shelter Cove Lodge" (S5). In effect, the sign is missing an enormous amount of rhetorical context: Lennox was a local artist; Shelter Cove is not a cove but a local hotel (today it's the "Best Western Shelter Cove"); and nothing about the image is historically truthful.

Lennox depicts a fantastical interpretation-and, in turn, creates a misremembrance- of a moment that probably never happened. In 1542, Cabrillo (following in Cortés's footsteps) first encountered the Ipai tribe near San Diego; he did not meet the Chumash on the Central Coast. Steven Hackel describes this moment in Children of Coyote, Missionaries of Saint Francis: Indian-Spanish Relations in Colonial California, 1769-1850: "When Cabrillo's men ventured ashore 'where there were some people,' all but three of the Indians fled" (32). Father Serra and his ilk will not arrive in Alta California for two more centuries, so it's unclear how this painting and its visual narrative relate to the mission. The origin story conveyed in the painting revises the past such that it becomes more gratifying to engage with in the present.

Mission SLO misses many opportunities to face its past. For instance, it actually makes sense that some Native artifacts in the museum lack context and explanation. Secularization created chaos. Mission ephemera-everything from furniture, tools, and artwork-were sometimes given to rancheros, some were stolen, and some were taken for safekeeping by the mission Natives themselves. Very few museums display objects that came from their own missions. Simply acknowledging this confusing time, rather than sticking to a rather dry timeline of events, could help visitors better understand the history of the spaces in which they stand. Instead, most missions offer a carefully crafted experience that asks visitors to empathize with the Franciscans. No one is comfortable calling out clergy and volunteers for cultivating false public memories and furthering a colonizing mindset; yet, when the museum has not changed for decades, the misrepresentation appears intentional and self-serving. The Chumash are depicted as historical, as though they have disappeared from the region. But they have not of course.

Wendy Lucas, a native Californian and member of the yak tity $u$ tity $u$ yak tithini ("all the people") Northern Chumash Tribe, contributed an editorial to the San Luis Obispo Tribune to recognize California's new "Indigenous Peoples Day," which replaced Columbus Day in 2017. She asserts: "The presence of Northern Chumash in our area dates back more than 10,000 years. ... Through all the challenges, attempts at direct and indirect annihilation of our people, we are still here. Through all the confiscation of our homelands/broken treaties/broken families/forbidden language, ceremonies, religion, culture ... we are still here" (par. 15). Mission SLO seems like an appropriate place to "name colonialism and its ongoing effects" (Lonetree 7), yet it remains oddly silent about its role in the treatment of Native people both today and in the past. Silence is, of course, a choice-one that La Purisima Mission does not make. 


\section{La Purisima Mission, Founded by Father Fermin de Lasuén in 1787}

Simply finding La Purisima (with the help of Google Maps) makes the entire endeavor feel different from visiting Mission SLO, which is surrounded by downtown shops and restaurants. I drive south through small towns with Spanish names, through farmland and vineyards, and past the entrance to an Air Force base. After about an hour, the sign for the mission just appears, seemingly in the middle of nowhere. La Purisima's large parking lot faces a modern museum and visitor's center, so it feels natural to begin my outing there; I cannot see the actual mission from the lot.

Park rangers in uniform and volunteers greet visitors entering the museum. Like Mission SLO, this museum is arranged in chronological order, but begins with Chumash life and customs before European contact. This timeline offers more depth and detail. A table featuring shells, baskets, and animal furs encourages visitors to "use [their] senses to explore materials used by the Chumash." An adjacent wall features a watercolor painting depicting Chumash men and boys harvesting mussels and fishing while women collect reeds for constructing a tulle home. The placard next to the image highlights the Chumash capacity "to become masters at managing and harvesting the coastal resources."

The museum moves visitors through time to the moment when Spanish colonizers made contact with the Chumash. At each step, signs speak to visitors in second person, asking them to empathize with the difficult choices made by both members of the Chumash tribe and the padres. For instance, a sign near the beginning of the museum positions readers as padres who were commanded to "Build a mission!" (emphasis in the original). The Chumash, included in a list of the padres' "meager resources," are depicted as having "skill and intelligence," and they are crucial for the construction of the mission. The sign's final question - "How can you fail?"- seems suspiciously sarcastic, yet the question also seems like a fair one. Another sign next to a life-size drawing of a Chumash man asks visitors to consider his perspective as he leaves one morning to

help the Spanish build temporary shelters and fortifications at the site of the new mission. In exchange for his labor, he hopes to receive a metal knife, glass beads, or other prized items from them. He also hopes their priest can cure the illness that has sickened his youngest child. ... [T] he padres (Catholic priests) urge the Chumash to move to La Purisima. Some accept their offer and find themselves living in two worlds. What choice would you make?

The gentle use of second person here and throughout the museum urges visitors to consider the experiences of everyone who contributed to the mission. Of course, it's impossible to know what we would do if navigating this worldwould we build a mission if told to do so by Spain or by the Franciscans? - but it's important to ask the questions. Placing oneself in the positions of both the padres and the Chumash is a marked shift from the approach at Mission SLO 
where visitors are asked to empathize almost exclusively with those who wielded power.

As visitors continue through the museum-which can easily take an hour or more to explore-mission life for the Chumash is a focal point. The museum concedes that while the "mission fulfills the Spanish vision" of claiming territory and religious conversion, the Chumash Natives' lives were increasingly difficult due to "corporal punishment and the regimented lifestyle. ... [A]s more Chumash die from disease, the work for those remaining grows more difficult, and discontent increases." The sense of collaboration and harmony that bubbles to the surface at Mission SLO is absent from this narrative. Rather, at La Purisima, Spanish colonization was driven by a series of decisions that granted Chumash Natives very little agency. This mission is seeking to address some of the harsher truths of mission life.

The museum also addresses the dissolution of the mission system and its effects on La Purisima. Without constant maintenance of their soft adobe walls, ${ }^{4}$ the missions literally began to melt. In the late nineteenth and early twentieth centuries, tourists and artists often captured images in photos and paintings depicting the strange beauty of the collapsed buildings, which, as the museum argues, "fuel[ed] the myth about mission life that has little resemblance to reality." The public's romance with the missions began in this moment.

After leaving the museum, visitors follow a dirt path to a small bridge with a sign: "Across this bridge lies California's eleventh mission and a glimpse of life during the 1820's [sic]. ... We hope you enjoy your visit to the past." When visiting La Purisima, wearing good walking shoes is advisable because the vast site covers 1,928 acres. ${ }^{5}$ The mission itself encompasses a sprawling building with dozens of rooms lining a long corridor full of open doors, each presenting a different facet of mission life. Some rooms portray how the padres would have lived and include period beds, desks, books, clothing, and tallow candles. Other rooms show the daily working life of the mission, including a stocked kitchen, blacksmithing equipment, and a tannery. Dormitories of Spanish soldiers include weaponry and devices for punishment, like stocks. The mission also has two churches, one for regular services the Chumash were required to attend and the other for private events, like baptisms. A small cross in a courtyard "stand[s] in memory of the early Californians who are buried in the cemetery"; there are no other headstones or markers. The mission grounds also support a working farm, complete with turkeys, pigs, horses, a long-horned steer, and chickens. There is also a lavandería, where the Chumash bathed and washed clothes. The monjerio has been preserved so visitors can see where women and girls were forced to spend nights.

\footnotetext{
${ }^{4}$ Adobe bricks were constructed of clay/mud, water, weeds or straw and left in the sun to dry.

${ }^{5}$ The mission originally encompassed 300,000 acres.
} 
Visiting La Purisima is a mostly outdoor pursuit in a serene landscape: birds chirp, animals graze, the wind blows, the sun is warm. Both La Purisima's and Mission SLO's tranquil elements show why these spaces are complicated: their bucolic settings can lull visitors into romanticizing and mis-remembering the past. La Purisima's rural setting, mission buildings, and museum are intended to complement each other, yet a disconnect persists. The Chumash voices and perspectives come through with some degree of clarity in the museum while the mission grounds privilege the padre's experiences. However, visitors can still experience the mission grounds and artifacts through the historical lens presented in the museum.

While Mission SLO seems to have communicated the same message decade after decade, La Purisima has slowly revised its approach to history. If we regard memories as engaging in a rhetorical process of meaning-making, it's important to look at the different meanings a site has crafted through time. Undoubtedly, La Purisima has not always been sensitive about the historical narrative it cultivates.

In 2009, the Travel Channel aired an episode of Ghost Adventures that focused on ghost sightings at La Purisima. The first few minutes of the episode offer a fairly accurate glimpse into the Spanish takeover of the Chumash land and culture. Host Zac Bagans asserts, "The Spanish came here and they stole the land from the Chumash Indians and forced the Chumash to convert to their religion." Bagans wonders if the suffering and death can be blamed for all the "trapped souls" at the mission. For expert testimony, he turns to La Purisima park rangers, volunteers in period dress, and a "psychic researcher/author." Bagans and his crew have secured permission to spend the night in the mission. They use their ghost hunting gear to study the apparent apparitions, noises, and "disembodied voices"; one "eyewitness" claims she heard the Chumash language being spoken in an empty room. To lure ghosts, they attach museum artifacts to a cameraman and play flute music.

I stumbled on this broadcast while channel surfing one afternoon. I was mesmerized not by the supernatural activity but by the way the ghost bros stomped around the sacred and historical space. Explaining away Native suffering by focusing on ghosts is alarmingly akin to a racist, cartoonish focus on "ancient Indian burial grounds." The episode concludes by showing the silhouette of what could only be a Spanish soldier their thermal camera picked up. The expert psychic is especially excited by the results: "I'm glad you got something verifiable that you can give to the public and say, "hey, stories of ghosts are based on fact!"”

When I took a tour of the mission with a park ranger in fall 2018, I wondered if the guide would discuss these verifiable ghosts. The tour was led by Jesse AguilerPerez, a young ranger who had worked at the state park for about two years (Figure 4). Immediately, Aguiler-Perez framed the purpose of his role as guide: "My job is to provide an interpretive history of the Native peoples." 6 As eight of us in the tour group walked the grounds for the next two hours, Aguiler-Perez

\footnotetext{
${ }^{6} \mathrm{I}$ am quoting Aguiler-Perez with his permission.
} 


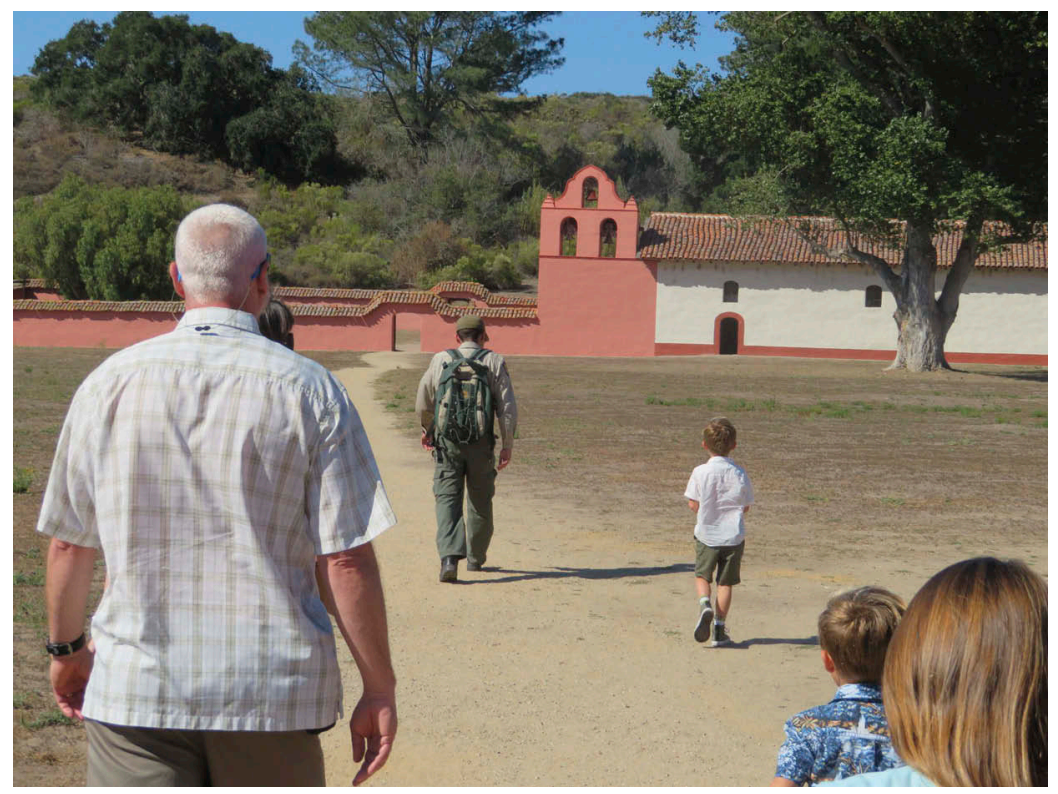

Figure 4 A tour group led by a La Purisima park ranger.

provided a historical account that both rivaled and seemed informed by the academic histories from which I have been learning. He relied on the term "Native" to refer to the Chumash, never once using "neophyte," the dominant term at Mission SLO.

Like the museum's signs, Aguiler-Perez asked us to put ourselves in the position of the Chumash. He explained that visitors often ask him "why the Native people stayed if they were treated so poorly." When faced with this question, he responds:

Use your imagination. You wake up in your tulle home, feeling the same breeze as your ancestors-but you see a ship, with men elegantly dressed. Then the Franciscans arrive. Your mind is blown. The young and curious join the mission system. Once you were joined, you could not leave without permission. The results were devastating for the people. ... In letters padres wrote [to Spain], they say that in country, [the Natives] thrive. Here, they fatten and die.

This scenario almost parallels the one presented in the Lennox painting, except it's laced with historical truth and empathy. Throughout the tour, Aguiler-Perez offered different viewpoints for us to consider. While standing in the military barracks, he highlighted the perspectives of soldiers stationed at every mission, explaining that they often received only tobacco and chocolate for payment. He pointed to a cross on a hill and the Spanish flag flying in front of the mission and described both as "symbols of power." While the Chumash were a constant focus, 
he also conceded that "no matter your opinion of the missions, the Franciscans felt this was their calling in life."

The final stop on the tour took us to the mission's infirmary. Aguiler-Perez again asked us to imagine what it was like "to see so much death and illness" at the mission. He reminded us that in pre-contact times, "Chumash Natives had a lifespan of 40 to 50 years. After contact, most Chumash didn't live past thirty; Native children often didn't live past four." As a final sentiment, Aguiler-Perez concluded his tour with an admitted cliché, but one that has real meaning to him: "never forget history in order to never repeat it." My fellow visitors and I stood awkwardly in the infirmary, unsure how to respond. One visitor piped up, "I have been on fifteen [mission] tours, and this was the best. That was incredible." And finally, it felt appropriate to applaud and thank our guide for his knowledge and the history he shared with us.

Aguiler-Perez generously stayed after the tour to answer everyone's questions, including mine. I asked if he had been to Mission SLO and wondered if he had any thoughts on its approach to history. He paused to choose his words carefully. The role of the mission, he explained, is to "respect and preserve" history, "not just for the Catholic Church, but for all of us." I also could not help but ask about the Ghost Adventures program. The show's title was barely out of my mouth before he smiled. The "past administration," he clarified, was responsible for that program. Such interpretive approaches are no longer allowed because "current park staff find it disrespectful." The show also brought to the mission tourists who were not interested in history; they just wanted to hear spooky stories. Although the episode aired ten years ago, tourists still ask if Aguiler-Perez has seen any ghosts.

\section{Decolonizing Memories}

The Ghost Adventures episode illustrates La Purisima's changing approaches to crafting a historical narrative. But we are not surrounded by ghosts. Ancestors of "mission Indians" still reside throughout the county and state, yet most missions discuss Natives as though they are ancient and absent. Aguiler-Perez's tour illustrates the evidence-based approach to history the mission has implemented. However, if visitors choose instead to seek out ghostly apparitions, they are missing the tangible, devastating impact the missions had on Native lives. La Purisima readily accepts its rhetorical responsibility to present competing narratives, and if the state park continues to decolonize its approach to history, it can build "momentum for healing, for community, and for restoring dignity and respect” (Lonetree 171).

For over a century, Californians have fought to save the missions, working with city, state, and county governments, as well as private donors, to raise substantial amounts of money to preserve them. For instance, in 1895, Charles Lummis, a journalist and historic preservation activist, formed the Landmarks Club of Southern California, which was "dedicated to the preservation of historical sites 
throughout California, starting with the Spanish missions" ("History"). In other words, California's missions are important because we have decided they should be. Yet tribal members have consistently spoken about the missions' traumatic impact on their heritage and ancestors, and maybe they will finally be heard. In her memoir, Bad Indians, Deborah A. Miranda recalls the multigenerational trauma her family lived through as a result of the "missionization of California" (xvi). More specifically, she argues for an end to the state's fourth-grade curriculum, which furthers a "Mission Fantasy Fairy Tale" that has

done more damage to California Indians than any conquistador, any priest, any soldado de cuera (leather-jacket soldier), any smallpox, measles, or influenza virus. This story has not just killed us, it has taught us how to kill ourselves and kill each other with alcohol, domestic violence, horizontal racism, internalized hatred. (xix)

California's required fourth-grade mission history curriculum creates a bond between citizens and missions they carry into adult life; the unit serves as the interface-the prosthetic-between history and memory.

Exactly how to teach mission history to fourth-graders has been an ongoing debate in the state. Building an elaborate mission model became a rite of passage (one that may penalize low-income students lacking funds to spend on missionbuilding kits). ${ }^{7}$ In a move that favors decolonization, the history framework developed by researchers at University of California, Davis, and adopted by the California State Board of Education in 2016 encourages teachers to "focus on the daily experience of missions rather than on the building structures themselves. Building missions from sugar cubes or popsicle sticks does not help students understand the period and is offensive to many" ("Grade" 76). The push to focus less on structures and more on cultures and peoples came as a welcome change to some educators and parents (many of whom built their own mission models as children). The Los Angeles Times editorial board welcomed the "impending death of the fourth-grade mission project": "If ever there was an educational reform that everyone should love, this is it" (Times). In effect, the state curriculum is slowly moving in a more progressive direction, and perhaps the missions will begin to follow the state's lead.

Statues of Serra stand in front of each religious mission. They have been defaced five times in recent years, indicating the mission's histories are indeed seeping out (Figure 5). Acts of vandalism increased in 2015 when Pope Francis canonized Serra, explaining that Serra "sought to defend the dignity of the native community, to protect it from those who had mistreated and abused it" (qtd. in Sanchez par. 5). During the ceremony in Washington, DC, tribal members and allies throughout California demonstrated at the missions. As many protest signs

\footnotetext{
${ }^{7}$ Most mission gift shops sell model kits that students can use to build a mission.
} 


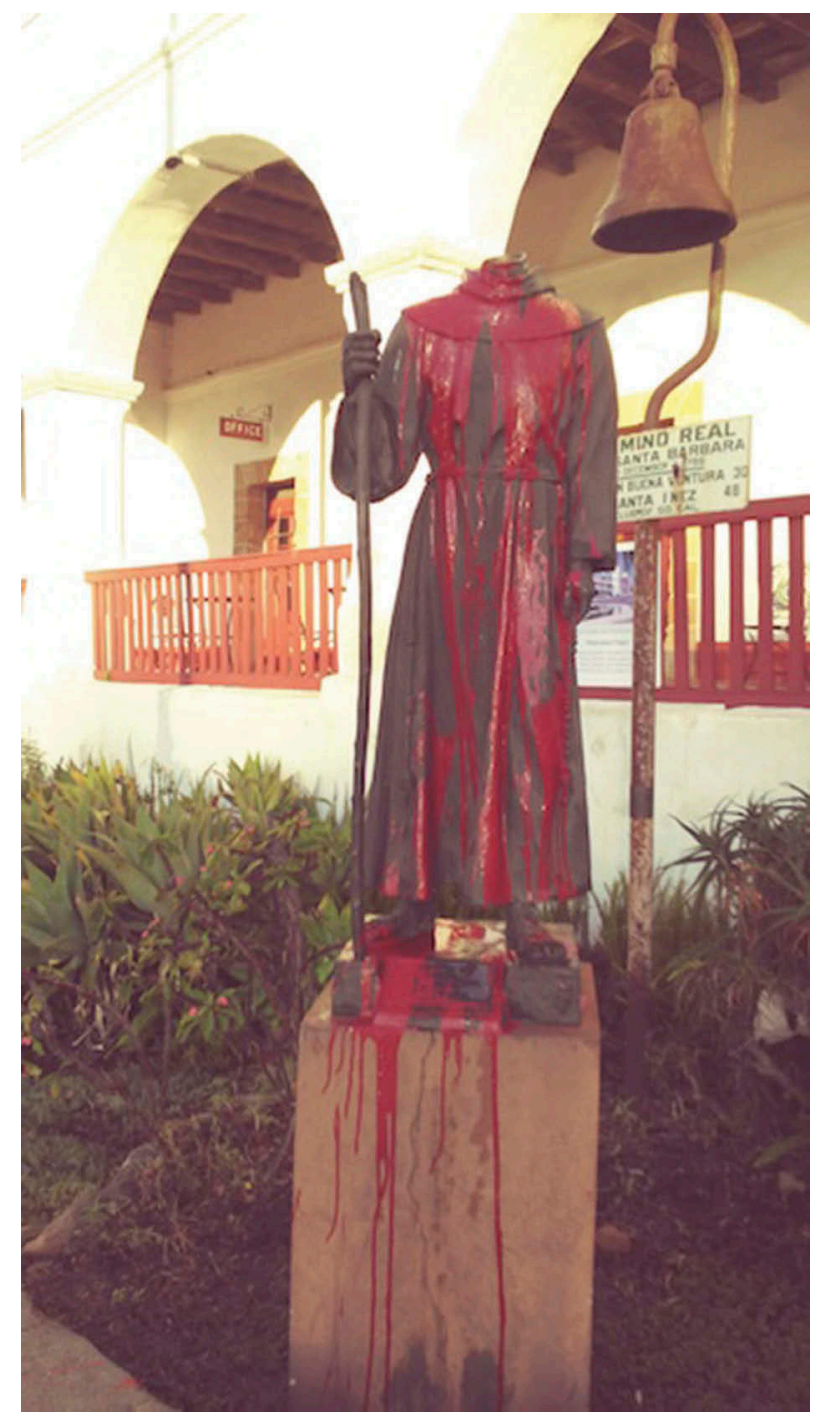

Figure 5 A vandalized Serra statue in front of Mission Santa Barbara. Printed with permission of edhat.com.

rebutted, Serra was no saint. Stan Rodriguez of the Santa Ysabel Indian Reservation protested at Mission Basilica San Diego de Alcala, "I believe [Serra] was an architect of a genocide, a cultural and physical genocide on our people" (qtd. in Sanchez par. 9).

Every state has a monument, statue, plaque, or building devoted to a historical figure whose contributions are perhaps more complicated than the site of remembrance indicates. As part of this movement to revisit past understandings, the 
American Civil War Museum recently opened in Richmond, Virginia. The museum's chief executive, Christy Coleman, suggests that, with regard to the Civil War, "memory has taken over the actual history, and ... collective memory is not historical in many cases" (qtd. in Bouie par. 2). The new museum seeks to address the public's mis-rememberings. Memorials are created in a present moment with the hope of shaping future memories, thus tracking these memories and contextualizing them as time passes seems essential.

Like cities with Confederate monuments, California is at a crossroads with its missions: we can continue to romanticize these sites, insisting they represent a moment of vitality and prosperity for all who encounter(ed) them. We can further the dominant narrative-a kind of invented past-and downplay aspects of the missions that may make tourists uncomfortable. Or we can bring to light counternarratives and create new public memories by using the missions to show how real lives have been shaped by their practices. I would like to see missions become decolonized spaces of healing rather than sites where those who were injured and harmed are silenced. In effect, historical locations that have traditionally represented the powerful and the privileged necessitate rhetorical inquiry. Museums and historical sites often function as terministic screens that further a dominant narrative while obscuring opportunities to create historical meanings that are both harder to grapple with and more accurate.

Both Lonetree and Onciul present decolonizing as a process. Implementing decolonizing practices-presenting competing viewpoints, addressing difficult truths surrounding abuse and mortality, addressing the grief Native communities may still feel today-aids in developing a more nuanced depiction of mission history. Further, missions can engage local communities in determining how to represent their histories, a move that shows a "willingness to share power and respect cultural practices, which can in turn help to strengthen relations between museums and the communities they represent" (Onciul 123). Collaborating with tribal members and historians to contextualize exhibits and present parallel narratives is an essential step in moving toward a decolonizing paradigm.

\section{Acknowledgments}

I thank the RSQ editor and reviewers for their thoughtful and constructive feedback. Your comments, questions, and suggestions helped me see my own work more clearly.

\section{Works Cited}

Aguiler-Perez, Jesse. Personal interview. 26 Oct. 2018.

Arnold-de Simine, Silke. Mediating Memory in the Museum: Trauma, Empathy, Nostalgia. London: Palgrave Macmillan, 2013. 7 Aug. 2019. PDF file.

Ashworth, G. J., Brian Graham, and J. E. Tunbridge. Pluralising Pasts: Heritage, Identity and Place in Multicultural Societies. London: Pluto, 2007. Print. 
Blair, Carol, Greg Dickinson, and Brian L. Ott. “Introduction: Rhetoric/Memory/Place.” Dickinson, Blair, and Ott 1-54. Print.

Bouie, Jamelle. "Undistorting the Civil War." The New York Times. 16 May 2019. Web. 16 May 2019.

Castillo, Elias. A Cross of Thorns: The Enslavement of California's Indians by the Spanish Missions. Fresno: Craven Street, 2015. Print.

Cook, Jim. "History Under Glass: Musty Archives Yield Finds-and Puzzles." San Luis Obispo County Telegram-Tribune. 30 Mar. 1978. A4. Print.

Cosson, Derek. "Transcript of New Orleans Mayor Mitch Landrieu's Address on Confederate Monuments." The Pulse Pensacola. 19 May 2017. Web. 20 Sept. 2018.

Dartt-Newton, Deana. "California's Sites of Conscience: An Analysis of the State's Historic Mission Museums." Museum Anthropology 34.2 (2011): 97-108. 6 May 2017. PDF file.

De La Pérouse, Jean François. Monterey 1786, Life in a California Mission: The Journals of De Jean Françoise La Pérouse. 1786. Rpt. Berkeley: Heyday, 1989. 51-111. Print.

Dickinson, Greg, Carol Blair, and Brian L. Ott, eds. Places of Public Memory: The Rhetoric of Museums and Memorials. Tuscaloosa: U of Alabama P, 2010. Print.

Gold Coast Calendar of Events: Ventura County. "Chumash Way..." Los Angeles Times. 10 Aug. 1986. X3. PDF file. 10 Oct. 2018.

"Grade Four-California: A Changing State." History-Social Science Framework for California Public Schools: Kindergarten Through Grade Twelve. California Department of Education, 2017. 67-94. Web. 25 June 2019.

Hackel, Steven. Children of Coyote, Missionaries of Saint Francis: Indian-Spanish Relations in Colonial California, 1769-1850. Chapel Hill: U of North Carolina P, 2005. Print.

"History of the Landmarks Program." California State Parks, Office of Historic Preservation. n.d. Web. 4 Sept. 2019.

Kohli, Sonali. "Stanford is Removing Junípero Serra's Name from Parts of Campus." Los Angeles Times. 16 Sept. 2018. Web. 16 Sept. 2018.

Jackson, Robert H., and Edward Castillo. Indians, Franciscans, and Spanish Colonization: The Impact of the Mission System on California Indians. Albuquerque: U of New Mexico P, 1996. Print.

“Junipero Serra Statue Beheaded at Old Mission." Edhat Santa Barbara. 11 Sept. 2017. Web. 7 Feb. 2019.

Kryder-Reid, Elizabeth. California Mission Landscapes: Race, Memory, and the Politics of Heritage. Minneapolis: U of Minnesota P, 2016. Print.

"La Purisima Mission." Ghost Adventures. By Jeffrey E. Belanger. Dir. Zak Bagans and Nick Groff. Travel Channel, 19 June 2009. Television.

La Purisima Mission State Historic Park Tour. Lompoc, CA. 26 Oct. 2018.

Landsberg, Alison. "Introduction." Prosthetic Memory: The Transformation of American Remembrance in the Age of Mass Culture. New York: Columbia UP, 2004. 1-24. Print.

Lonetree, Amy. Decolonizing Museums: Representing Native America in National and Tribal Museums. Chapel Hill: U of North Carolina P, 2012. Print.

Lucas, Wendy. "Indigenous Peoples Day Helps Shine the Light of Truth on California's Dark Past." The San Luis Obispo Tribune. 27 Oct. 2017. Web. 3 Dec. 2018.

Mancino, Susan. "A Communicative Review of Museums." Review of Communication 15.3 (2015): 258-73. PDF file. 6 Aug. 2019.

Margolin, Malcolm. "Introduction." Monterey 1786, Life in a California Mission: The Journals of Jean Françoise De La Pérouse. 1786. Rpt. Berkeley: Heyday, 1989. 3-50. Print.

Mission San Luis Obispo Tour. San Luis Obispo, CA. 7 Sept. 2018.

Miranda, Deborah A. Bad Indians: A Tribal Memoir. Berkeley: Heyday, 2013. Print. 
Onciul, Bryony. Museums, Heritage, and Indigenous Voice: Decolonising Engagement. New York: Routledge, 2015. Print.

“Pastor's Message." Mission San Luis Obispo de Tolosa. n.d. Web. 1 Dec. 2018.

Poirot, Kristan, and Shevaun Watson. "Memories of Freedom and White Resistance: Place, Tourism, and Urban Slavery." Rhetoric Society Quarterly 45.2 (2015): 91-116. Print.

Reyes, Bárbara O. Private Women, Public Lives: Gender and the Missions of California. Austin: U of Texas P, 2009. Print.

Reynolds, Nedra. Geographies of Writing: Inhabiting Places and Encountering Difference. Carbondale: Southern Illinois UP, 2004. Print.

Roberts, Carol. "Inner Beauty." The Tribune. 2001. A1, A11. History Center of San Luis Obispo County. Print.

Sanchez, Tatiana. "Junipero Serra Canonization Draws Protests." The San Diego Union Tribune. 23 Sept. 2015. Web. 5 Feb. 2019.

Sandos, James. Converting California: Indians and Franciscans in the Missions. New Haven: Yale UP, 2004. Print.

Solnit, Rebecca. Infinite City: A San Francisco Atlas. Oakland: U of California P, 2010. Print.

Times Editorial Board. "Editorial: Good Riddance to California's 'Mission Project."' 19 Sept. 2017. Web. 4 Sept. 2019.

"Welcome to Mission San Luis Obispo de Tolosa." Pamphlet. Mission San Luis Obispo. Print. 